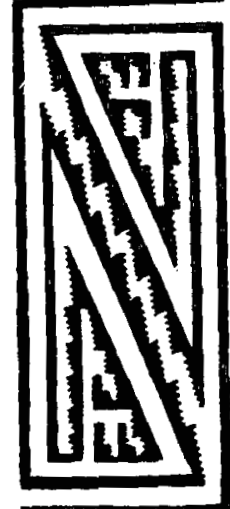

MONITORING ENVIRONMENTAL AND RELATED PERFORMANCE PARAMETERS FOR A RANKINE-CYCLE TURBINE ELECTRIC GENERATOR UTILIZING GIEOTHERMAL ENERGY AT THE GILA. HOT SPRINGS, NEW MEXICO

Arlene H. Starkey

Larry lcerman

August 1984

New Mexico Energy Research and Development Institute 


\section{DISCLAIMER}

This report was prepared as an account of work sponsored by an agency of the United States Government. Neither the United States Government nor any agency Thereof, nor any of their employees, makes any warranty, express or implied, or assumes any legal liability or responsibility for the accuracy, completeness, or usefulness of any information, apparatus, product, or process disclosed, or represents that its use would not infringe privately owned rights. Reference herein to any specific commercial product, process, or service by trade name, trademark, manufacturer, or otherwise does not necessarily constitute or imply its endorsement, recommendation, or favoring by the United States Government or any agency thereof. The views and opinions of authors expressed herein do not necessarily state or reflect those of the United States Government or any agency thereof. 


\section{DISCLAIMER}

Portions of this document may be illegible in electronic image products. Images are produced from the best available original document. 


\title{
MONITORING ENVIRONMENTAL AND RELATED PERFORMANCE PARAMETERS FOR A RANKINE-CYCLE TURBINE ELECTRIC GENERATOR UTILIZING GEOTHERMAL ENERGY AT THE GILA HOT SPRINGS, NEW MEXICO
}

Final Techrical Report

\author{
Principal Investigators: \\ Arlene H. Starkey \\ Larry lcerman \\ New Mexico State University Energy Institute \\ Las Cruces, New Mexico 88003 \\ Authors: \\ Larry :Lerman \\ Arlene H. Starkey
}

August: 1984

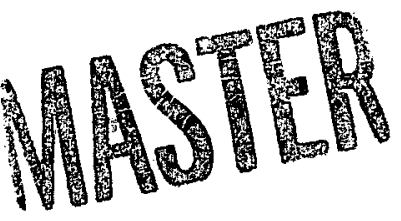

The work from which this material is drawn was the result of a project supported by the New Mexico Energy Research and Development Institute. The content, however, is the responsibility of the authors. 
BIBLIOGRAPHIC DATA SHEET

for reports sponsored by the

New Mexico Energy Research and Development Institute Santa Fe, NM 87501

\begin{tabular}{|c|c|}
\hline 1. & \begin{tabular}{c|c|cc} 
NMERDI REPORT NO. & 2. PUBLICATION DATE \\
$2-69-2209$ & August 1984 & NO. OF PAGES & 17
\end{tabular} \\
\hline 4. & $\begin{array}{l}\text { TITLE AND SUBTITLE } \\
\text { Monitoring Environmental and Related Performance Parame- } \\
\text { ters for a Rankine-Cycle Turbine Electric Generator Uti- } \\
\text { lizing Geothermal Energy at the Gila Hot Springs, New } \\
\text { Mexico }\end{array}$ \\
\hline 5. & $\begin{array}{l}\text { AUTHORS } \\
\text { Larry Icerman and Arlene H. Starkey }\end{array}$ \\
\hline 6. & $\begin{array}{l}\text { NAME AND ADDRESS OF PERFORMING ORGANIZATION } \\
\text { New Mexico State University Energy Institute } \\
\text { Box } 3 \text { EI, Las Cruces, NM } 83003\end{array}$ \\
\hline 7. & $\begin{array}{l}\text { ABSTRACT } \\
\text { This project was undertaken to provide data to state and } \\
\text { federal regulatory groups on the environmental effects, if } \\
\text { any, associated with the operation of a privately-owned } \\
\text { Rankine-cycle turbine-generator unit using low-temperature } \\
\text { geothermal resources in the form of free-flowing hot } \\
\text { springs to produce electricity in a remote, rural area. } \\
\text { Because the turbine-generator system to be monitored was } \\
\text { never on-line for a substantial period during the project, } \\
\text { no environmental conclusions can be drawn. The following } \\
\text { conclusions pertain to the operation of the turbine-gener- } \\
\text { ator system: (1) the heat exchanger could not provide } \\
\text { sufficient freon vapor at the required pressures to pro- } \\
\text { vide adequate thermal input to the turbine; (2) conver- } \\
\text { sion or redesign of the condenser and return pump to } \\
\text { function adequately represents a problem of unknown diffi- } \\
\text { culty; (3) all pressure and heat transfer tests indicat- } \\
\text { ed that a custom-designed heat exchanger built on-site } \\
\text { would provide adequate vapor at pressures high enough to } \\
\text { power a 10-kwe or perhaps larger generator; and (4) auto- } \\
\text { mated control systems are needed for the hot and cold } \\
\text { water supplies and the freon return pump. }\end{array}$ \\
\hline 8. & $\begin{array}{l}\text { KEY WORDS } \\
\text { Environmental data monitoring; Geothermal energy; Gila Hot } \\
\text { Springs; Rankine-cycle turbine-generator }\end{array}$ \\
\hline 9. & $\begin{array}{l}\text { AVAILABILITY } \\
\text { Copies of this report are available from the New Mexico } \\
\text { Energy Research and Development Institute Information } \\
\text { Center, University of New Mexico, Suite M, } 457 \text { Washington } \\
\text { SE, Albuquerque, NM } 87108 \text {. Tel. (505) } 277-3661 \text {. Please } \\
\text { inquire as to price. }\end{array}$ \\
\hline
\end{tabular}


$\underline{\text { Page }}$

List of Figures. . . . . . . . . . . . . . . . iv

1.0 Project Background . . . . . . . . . . . . . 1

2.0 Gila Hot Springs Area. . . . . . . . . . . . 1

3.0 Rox International Rankine-cycle

Turbine-Generator Unit. . . . . . . . . . 2

3.1 System Design . . . . . . . . . . . . 2

3.2 Site Preparation. . . . . . . . . . . 5

4.0 Environmental Assessment . . . . . . . . . 6

4.1 Monitoring System Design. . . . . . . . . 7

4.1.1 Rankine-Cycle Turbine-Generator. . . . 8

4.1.2 Gila River . . . . . . . . . . 8

4.1.3 Cold Water Collection System... . . . 10

4.1.4 Gila Hot Springs........... . . . . . .

4.1.5 Hot Water Collection System. . . . . . .11

4.1.6 Additional Monitored Parameters. . . . 11

4.2 Project Execution . . . . . . . . . . . 11

4.2.1 Water Rights Issues. . . . . . . . . . 11

4.2.2 Turbine-Generator System Tests... . . 13

5.0 Conclusions. . . . . . . . . . . . . 16

6.0 Acknowledgment . . . . . . . . . . . . . 17 


\section{LIST OF FIGURES}

Figure Page

1 Location map for the Gila Hot Springs area... . 3

2 Schematic diagram of the $10-\mathrm{kw}$ organic Rankine-cycle turbine-gererator unit at the Gila Hot Springs. . . . . . . . . 4

3 Schematic diagram of the ervironmental monitoring system for the $10-\mathrm{kw}$ organic Rankine-cycle turbine-generator unit at the Gila Hot Springs . . . . . . . . . 9 


\subsection{Project Background}

This project was undertaken to provide data to state and federal regulatory agencies on the environmental effects, if any, associated with the operation of a privately-owned Rankine-cycle turbine-generator unit using low-temperature geothermal resources in the form of free-flowing hot springs to produce electricity in a remote, rural area. The specific objectives of the monitoring program were to: (1) measure the continuous performance of the Rankine-cycle turbine-generator unit to determine the operational efficiency as a function of the flow rates and temperatures of the hot and cold water supplies; (2) detect changes, if any, in the local environment resulting from the operation of the system; (3) disseminate information or the performance of the turbinegenerator unit; and (4) provide an environmental impact assessment of the system to the appropriate regulatory agencies and to other potential operators of similar units.

\subsection{Gila Hot Springs Area}

The Gila Hot Springs are located in southwestern New Mexico ( $T 13 \mathrm{~N}, \mathrm{R} 13 \mathrm{~W}$, Section 5) and arise on the west Fork of the Gila River in northern Grant County, approximately 40 miles north of Silver City, New Mexico. There are a total of 41 springs, discharging a total of about 200 gallons/minute of hot water, ranging in temperature from 131 to $152.5^{\circ} \mathrm{F}$. Much of this water discharges from fractures in the rock 10 to 20 feet above the 
West Fork of the Gila River, with some discharging directly into the river. These springs are among the hottest of several warm and hot springs in the upper part of the Gila River Basin. All of the springs are located in an area classified by the U.S. Department of the Interior as the Gila Hot Springs Known Geothermal Resources Area (KGRA).

Property belonging to D.A. (Doc) and Ida Cambell and others straddles the river and is surrounded by the Gila Wilderness Area, the Gila National Forest, and the Gila Cliff Dwellings National Monument (see Figure 1). The Cambells had previously built a hot water collection system that diverts some of the free-flowing spring water and taps adjacent hot water wells for space heating. This system also serves as the primary potable water supply for the commercial operations on their property. Approximately $\$ 47,000$ was invested by the Cambells to develop the geothermal resources of the Gila Hot Springs area. Doc Cambell received an award of $\$ 32,000$ from the U.S. Department of Energy Appropriate Technology Grants Program, which was supplemented with $\$ 9,000$ of private funds, to purchase, install, and operate a $10-k w_{e}$ Rox International Rankine-cycle turbine and induction generator.

\subsection{Rox International Rankine-Cycle Turbine-Generator Unit}

\subsection{System Design}

The major components of the $10-\mathrm{kw}$ e turbine-generator system are shown in Figure 2. Four hot springs were developed to pro- 


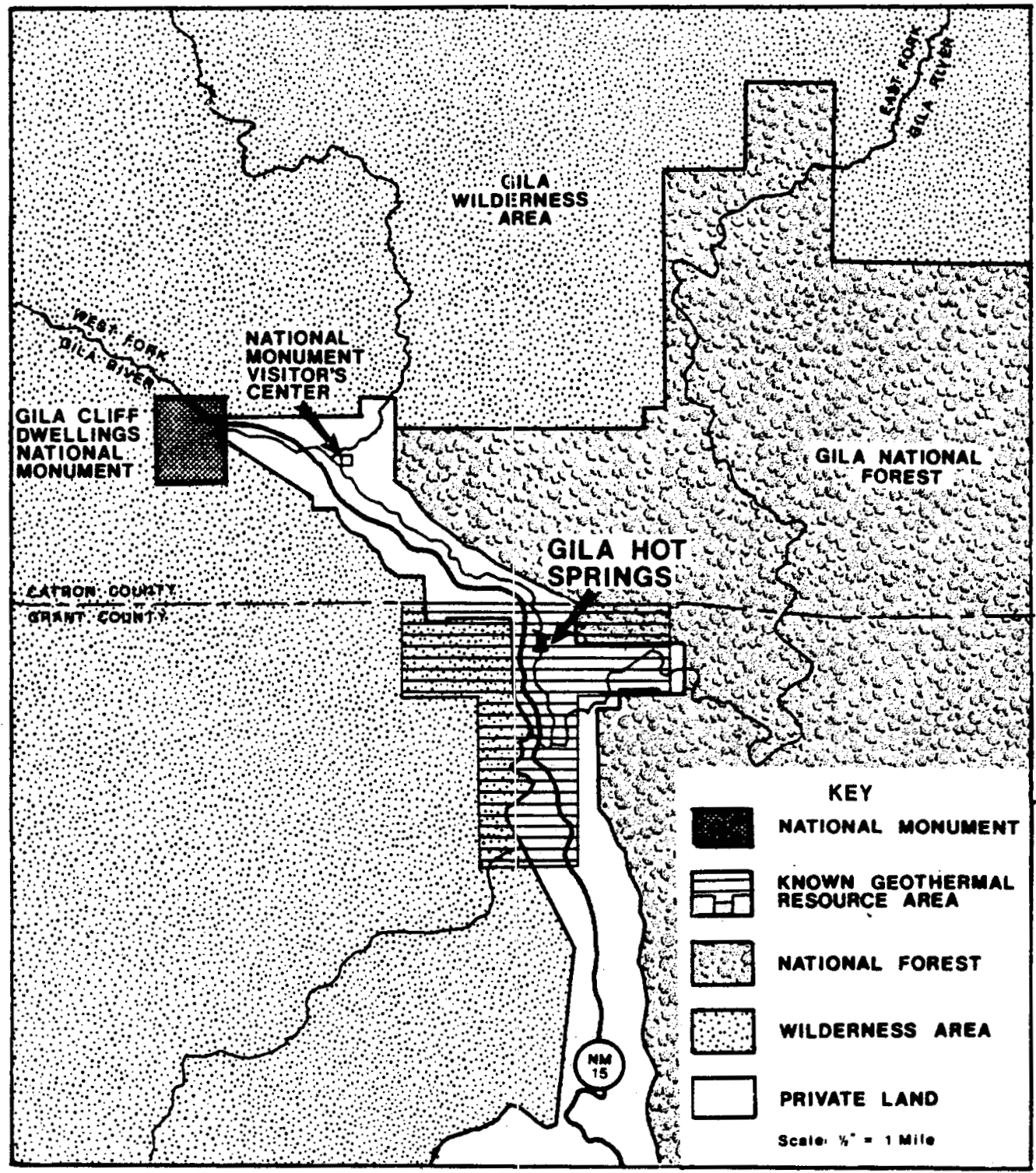

Figure 1. Location map for the Gila Hot Springs area. 


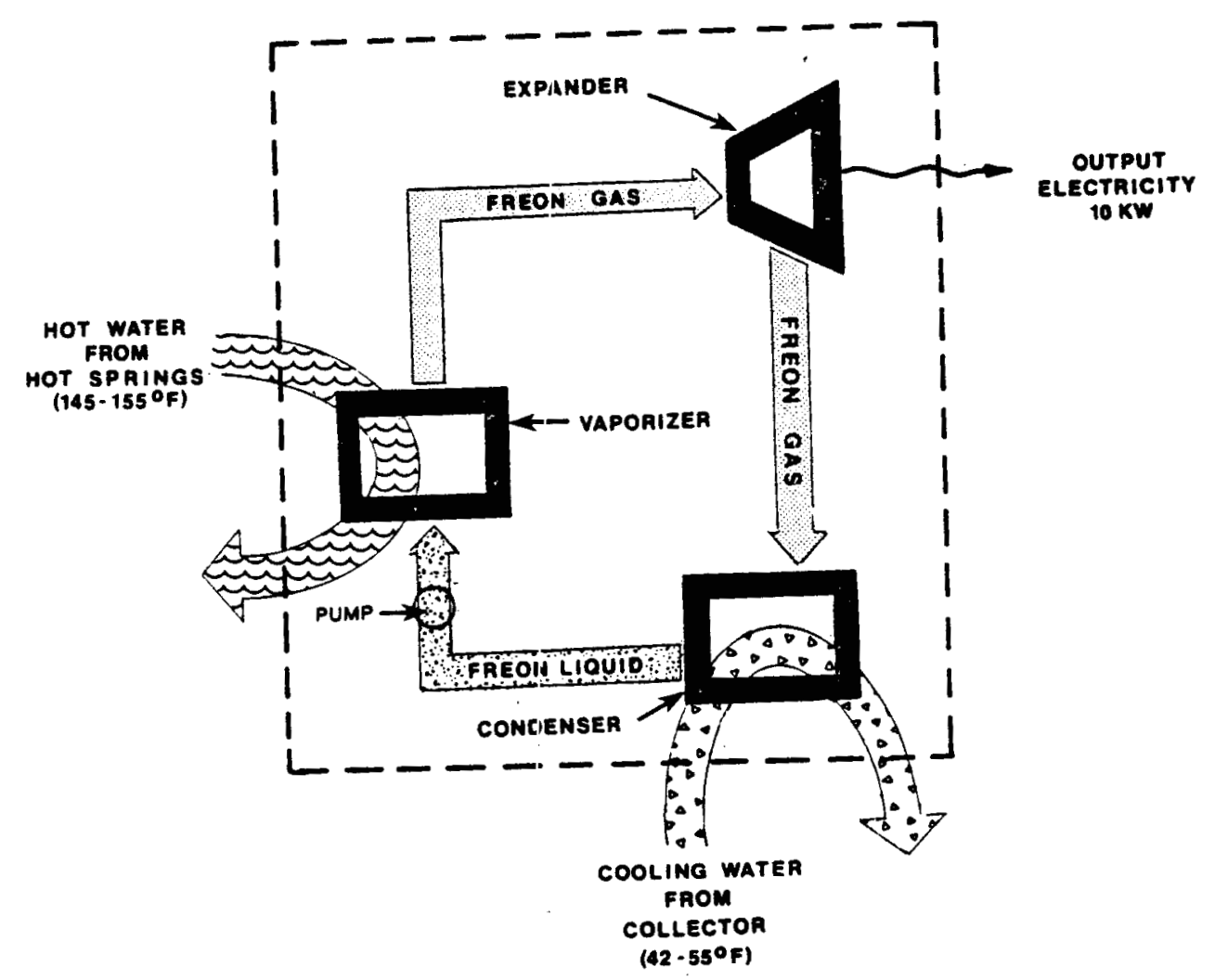

Figure 2. Schematic diagram of the $10-\mathrm{kw}$ organic
Ranking-cycle turbine-generator unit
at the Gila Hot Springs. 
vide 145 to $155^{\circ} \mathrm{F}$ water for the Gerotor Power System (i.e., the trade name for the organic Rankine-cycle turbine and induction generator). The geothermal water is collected in a hot water line and delivered to the polver unit. The hot water passes through a heat exchanger (vaporizer) where the geothermal heat is used to convert liquid freon to gaseous freon. The freon gas is expanded through a turbine to produce rotational power to drive an induction generator. The freon gas exhausted from the turbine enters a second heat exchanger (condenser) where the gas is cooled by water at a temperature of 42 to $55^{\circ} \mathrm{F}$ collected from the West Fork of the Gila River. The condensed freon is then pumped to the vaporizer for reheating. The hot water exhausted from the vaporizer is discharged into the space heating system, the potable water supply, or the Gila River depending upon the time of the year. All of the cooling water is returned to the Gila River.

\subsection{Site Preparation}

In order to collect the necessary hot water, several springs that had never been tapped were cleared of overburden, boxed in with concrete, and piped to the turbine-generator installation site. The temperature of these springs ranges from 149 to $152.5^{\circ} \mathrm{F}$. The complete hot water collection system consists of 530 feet of $11 / 4$ - to 2 1/2-inch galvanized pipe.

A cold water sump was dug 450 feet upstream of the turbinegenerator site on the West Fork of the Gila River, which has a water temperature of about $40^{\circ} \mathrm{F}$ in the winter. The water temper- 
ature rises several degrees during the summer months to a maximum of $55^{\circ} \mathrm{F}$. The cold water collection system, including the sump pump, contains a total of 450 leet of 3 -inch plastic pipe.

The minimum required temperature difference between the hot and cold water used to operate the turbine-generator unit is $100^{\circ} \mathrm{F}$. The hot and cold water collection systems at the site are, to within a few degrees, ordinarily able to provide this temperature difference year-round.

Prior to the installation of the Rankine-cycle unit, a concrete foundation and floor were laid at the installation site. The unit was placed on the concrete slab and anchored with bolts. A 10-foot by 15-foot steel building was erected around the unit with a standard overhead garage door installed at one end.

On the slope above the building, a concrete wall with a trench and drainage system was installed to protect the building from excessive runoff. All of the free-flowing hot water near the site was covered and contained to prevent access to the turbine-generator site and to reduce the naturally escaping steam from condensing on the inside and outside of the building. Installation of the turbine-generator unit was completed at the site on February 20, 1981.

4.0 Environmental Assessment

Because of the contiguous location of the Gila Hot Springs to the Gila Cliff Dwellings National Monument, the Gila Wilderness Area, and the Gila National Forest, the New Mexico State 
University Energy Institute proposed to conduct an environmental impact study of the operation of the turbine-generator system onsite at the Cambell property. A data monitoring system was to be designed to document the effects on the nearby hot springs and wells and to record possible changes in the physical and chemical characteristics of the Gila River resulting from operation of the system. This study was funded initially by the New Mexico Energy and Minerals Department and was to be conducted in conjunction with W.K. Summers \& Associates, Inc. of Socorro, New Mexico.

\section{1 Monitoring System Design}

The operation of the turbine-generator unit was believed to have the possibility of altering the stream flow, temperature, and/or water chemistry in the Gila River, thus perhaps adversely impacting the natural environment of the area. In order to document and quantify any changes in the environment directly attributable to the operation of the turbine-generator system, a monitoring system was designed to measure flow rates, water temperatures, and water chemistry of the Gila River, both above and below the installation site; the flow rates and temperatures in the hot and cold water collection and distribution systems on both the entrance and exit sides of the turbine-generator unit; and the flow rates, water temperatures, and water chemistry of the hot springs. In addition, the power generated by the turbine-generator system, the water levels in adjacent existing wells, and the ambient air temperatures and pressures were to be monitored. 
The continuous measurement system utilized thermistors, orifices with differential pressure transducers and totalizing meters, and pressure transducers tied into on-site recording equipment to gather the data. Periodic on-site visits were scheduled to make the necessary manual measurements to augment the recorded data.

Figure 3 is a schematic diagram showing the location of the water temperature sensors, the water flow meters, the staff gage and stage recorder, the water level recorders, the watt meter, and the barometer and thermograph included in the environmental monitoring system. The monitoring system was designed and installed by W.K. Summers \& Associates, Inc.

\subsubsection{Rankine-Cycle Turbine Generator}

The Rankine-cycle turbine-generator power output was instrumented in order to monitor changes in the operating efficiency of the system. These changes were to be correlated with changes in environmental factors to determine what effect, if any, natural changes in the flow rates and temperatures of the hot and cold water supplies had on the operating efficiency of the turbinegenerator unit.

4.1.2 Gila River

In order to establish baseline data, instrumentation was installed in the Gila River to measure stream flow rate and water temperatures. Periodic chemical analyses of the river water were also planned. These data would allow estimates to be made of changes in the river water composition as a function of the river flow rate both upstream and downstream from the turbine- 


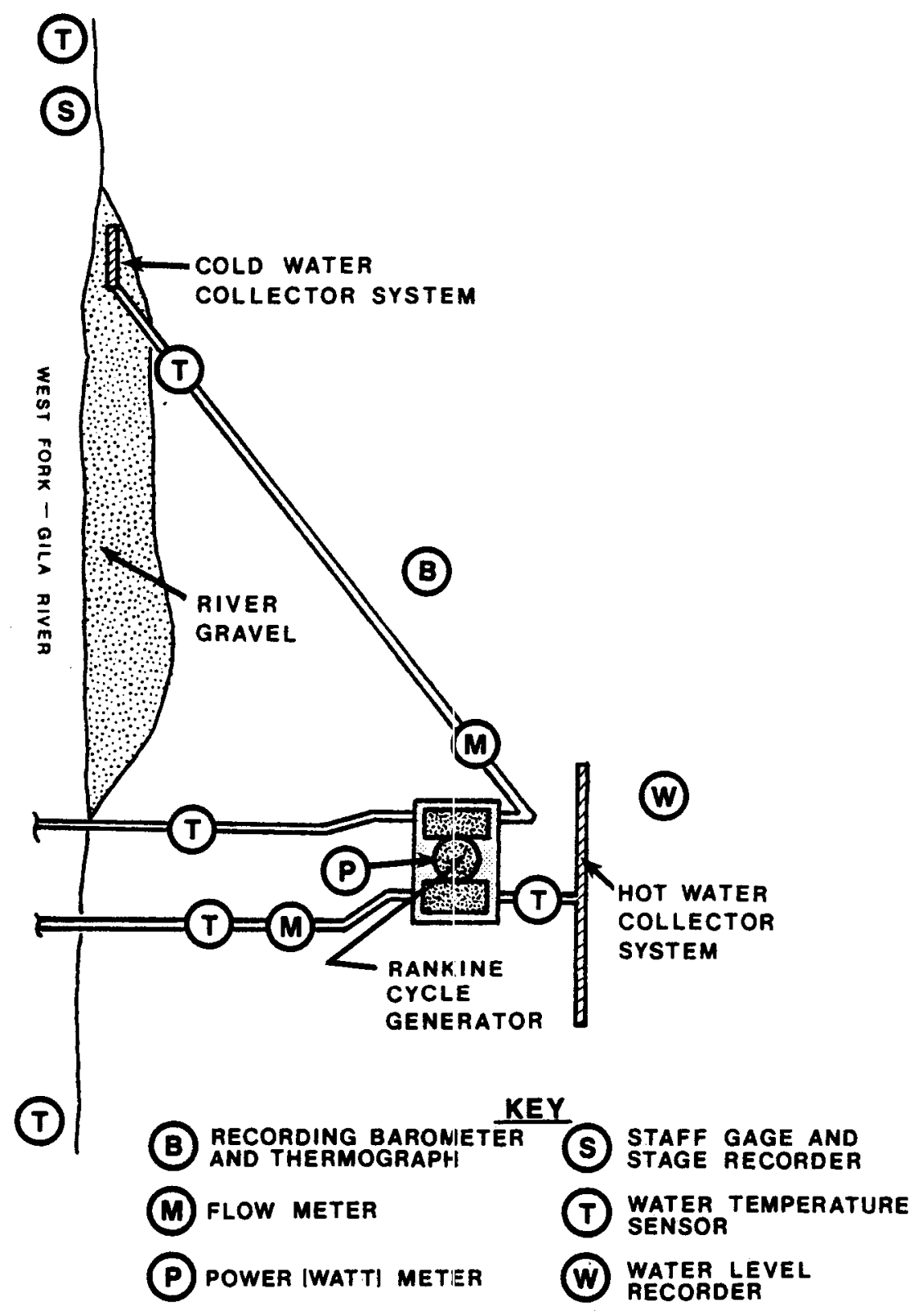

Figure 3. Schematic diagram of the environmental monitoring system for the $10-\mathrm{kw}$ organic Rankine-cycle turbine-generator unit at the Gila Hot Springs. 
generator site. This procedure would provide some data on the chemical contributions to the Gila River from the free-flowing springs prior to the operation of the turbine-generator and would detect any changes in the chemical composition of the river water during the operation of the system.

\subsubsection{Cold Water Collection System}

The availability of cold water from the collection system upstream of the turbine-generator is a function of the natural stream flow of the Gila River. Thus, variations in the cold water collection rate due to river stage were to be analyzed to determine expected variations in the turbine-generator power output. The volume and temperature of the cold water before and after passing through the condenser were to be monitored also to establish how closely the turbine-generator unit operated to the design specifications and what effects the increased temperature of the cold water supply had upon re-entry into the Gila River. To meet the New Mexico Water Quality Control Commission regulations, the temperature of the Gila River should not exceed $82.4^{\circ} \mathrm{F}$ in the area of the cold or hot water discharge, the pH of the water should remain in the range of 6.8 to 8.8 , and the dissolved oxygen content should be greater than $5.0 \mathrm{mg} / 1$.

\subsubsection{Gila Hot Springs}

The Gila Hot Springs are a collection of springs and seeps that extend from the bed of the Gila River up the east bank. An area of about 22,000 square feet contains the springs. A detailed map $^{*}$ was to be prepared to show the spatial distribution of

W.K. Summers \& Associates did not provide this map or any of the data to be collected as part of this project. 
the springs and the water discharge rate, temperature, $\mathrm{pH}$, and specific conductance at each discharge point. These data for the springs were to be monitored periodically to determine changes that might have occurred during the operation of the turbinegenerator unit.

4.1.5 Hot Water Collection System

The hot water collection system was to be monitored for volume and temperature before and after passing through the vaporizer to determine how closely the turbine-generator unit operated to the design specifications. The effluents of this system were designed to be discharged into the adjacent space heating system, the potable water supply, or the Gila River depending upon the time of the year.

\subsubsection{Additional Monitored Parameters}

Water levels were to be monitored in observation wells near the turbine-generator site to detect any disturbance in the natural subsurface head distribution. Ambient air temperature and pressure data were to be collected to provide baseline information.

\subsection{Project Execution}

\subsubsection{Water Rights Issues}

The Rankine-cycle system was installed at the Gila Hot Springs in February 1981. In March 1981, local residents, who had previously obtained geothermal rights from Doc Cambell, filed a petition with the New Mexico state Engineer to force Doc Cambell to prove that the operation of a geothermally-powered 
turbine-generator unit would not interfere with their geothermal rights. Negotiations with all parties on the initial issues were concluded in August 1981.

The environmental monitoring project, funded on March 10 , 1981, was delayed nearly six months by the geothermal rights negotiations. This project was finally initiated on september 1, 1981. Negotiations were inmediately undertaken to complete the subcontract between New Mexico State University, the prime contractor on the project, and W.K. Summers \& Associates, Inc., the subcontractor for the design, fabrication, installation, and operation of the environmental monitoring system. The subcontract was completed and approved by all necessary entities in late December 1981.

W.K. Summers \& Associates, Inc. completed the monitoring system design and ordered the required components during January 1982. Due to difficulties in getting suppliers to respond in a timely fashion, the last of the components for the monitoring system arrived in Socorro in July 1982. By now the project had been delayed 15 months from the original work schedule.

During part of this period, additional water rights issues were raised with the New. Mexico State Engineer. In spite of a court order in 1967 granting Doc Cambell the use of 196 acre-feet of water from the hot springs area of the Gila Hot Springs Subdivision, rights to use the water for electricity generation were not approved until a final hearing in August 1982, when the original 1967 decision was upheld. Even if the monitoring equipment had been delivered and installed earlier in the year, the 
system could not have been placed on-line except for brief testing during the period of the geothermal rights negotiations.

4.2.2 Turbine-Generator System Tests

During various testing sequences carried out in 1982 and 1983, numerous mechanical problems developed in the operation of the turbine-generator unit. The rigid bronze and copper return plumbing for the condensed freon and the pipe-to-sight glass indicating the fluid level failed. These failures resulted in freon being lost from the system. The rigid return plumbing was replaced with braided and reinforced high-temperature flexible hose. Additional Freon 12 was added to replace that which had been lost. Nevertheless, more freon leaks were detected. At this point, the manufacturer of the turbine-generator system traveled to Gila Hot Springs, during which time most threaded connections were silver-soldered, two flexible hoses that had failed were replaced, the system was cleaned of hose debris, and the lost Freon 12 was replaced.

Further testing of the system indicated that power was being produced at a rate below the design specifications. A series of improvements were undertaken to increase the power output. The designer of the system recommended increasing both the hot and cold water flows and a reduction in the displacement space within the turbine unit. Larger pumps and more hot springs were connected to increase the supply of hot water to the system. When these changes did not increase substantially the power being produced, the designer further recommended changing heads on the boiler tube (vaporizer) to convert the design from a six-pass to 
a three-pass head so that more hot water could be passed through the vaporizer.

Following a three-month delay, the modified boiler heads were obtained from York Manufacturing and were installed on-site. Testing was resumed but the power level did not increase sufficiently because the freon return pump was now not able to transfer the liquid freon from the condenser to the vaporizer at a rate equal to the vapor production rate. New variable belt sheaves were installed to increase the rotational speed of the return pump. The designer furtrer recommended switching to Freon 22 and changing heads on the condenser tube to three-pass heads. These modifications were made and tested.

As the environmental monitoring system was being assembled, test runs with the turbine-generator unit indicated that the vaporizer was too small to produce gaseous freon at the rate necessary for the production of $10 \mathrm{kw}$ of power. Doc Cambell, with the aid of the system designer and manufacturer, failed to find a manufactured heat exchanger with acceptable design specifications. Consequently, Allen Cambell, Doc Cambell's son, designed and manufactured a counterflow heat exchanger that was installed in May 1983. This heat exchanger measured 10 feet $x 7$ feet $x 6$ inches and was too large to be installed within the building housing the turbine-generator system. As a result, this unit was installed outside on the west side of the building. After instaliation of the new heat exchanger, test runs were conducted. The results were inconclusive, so 90 pounds of addi- 
tional freon were added to the system. Further testing indicated that the system had other severe operating problems.

During the next testing series, the flexible hose installed between the condenser and the return pump failed. An extensive search for flexible tubes to handle the Freon 22 at high pressures further delayed the project. Finally, all-metal flex hose, seals, and O-rings that were compatible with Freon 22 were located, ordered, received on-site, and installed. Before testing could be resumed, the Gila River flooded, damaging the cold water sump and washing out the road to the hot springs. This portion of the system then required considerable changes and restoration prior to starting continuous operation. Subsequently, a contractor excavated and cleared the area for an enlarged cold water sump and rebuilt the road. As of late 1983, Doc Cambell had run out of time and funds to continue the project.

During this period of repeated testing and redesign of the turbine-generator unit, the environmental monitoring system was completed and installed. Field testing of this system was initiated in April 1983. Due to the various problems encountered with the operation of the turbine-generator unit, no useful environmental data were gathered to complete the project as originally designed.

Following a careful review of the progress to date and the problems encountered, the New Mexico State University Energy Institute recommended that the environmental monitoring project be concluded at the end of December 1983 as scheduled because continuation of the project was unlikely to result in the collec- 
tion of useful data unless the mechanical problems with the turbine-generator unit were solved. Because Doc Cambell was not able to continue operating the system and/or improving the design, the project was concluded in December 1983. Throughout the course of the project, W.K. Sumners \& Associates provided the New Mexico State University Energy Institute with no environmental data and, thus, defaulted on the subcontract.

\subsection{Conclusions}

The following conclusions pertain to the operation of the turbine-generator system:

(1) the York heat exchanger (vaporizer) could not provide sufficient freon vapor at the required pressures to provide adequate thermal input to the $10-\mathrm{kw}$ turbinegenerator unit, using the $150^{\circ} \mathrm{F}$ geothermal water available at the site;

(2) conversion or redesign of the condenser and return pump to function adequately represents a problem of unknown difficulty;

(3) all pressure and heat transfer tests indicated that the custom-designed heat exchanger built on-site would provide adequate vapor at pressures high enough to power not only the $1 \mathrm{Cl}-\mathrm{kw}$ e generator, but probably a larger system; and

(4) automated control systems need to be developed for the hot and cold water supply systems and the freon return pump. 
Because the turbine-generator system was never on-line for a substantial period during the project, no environmental conclusions can be drawn from the project.

\subsection{Acknowledgment}

D.A. Cambell provided substiantial documentation and numerous personal recollections to the authors during the preparation of this report. Without his generous cooperation, this report could not have been prepared. 